\title{
Challenges of anemia correction during radiotherapy and chemoradiation
}

\author{
D. Rades 1 , S. E. Schild²
}

1Department of Radiation Oncology, University Hospital Schleswig-Holstein, Lubeck, Germany

2Department of Radiation Oncology, Mayo Clinic Scottsdale, Arizona, USA

Received 3 November 2011; accepted 1 February 2012

The effect of radiotherapy depends on optimal tumour oxygenation, as tumour hypoxia impairs the production of radiation-induced cytotoxic free radicals resulting in less tumour cell kill. The range of haemoglobin levels optimal for tumour oxygenation is $12-14 \mathrm{~g} / \mathrm{dl}$ in women and $13-15 \mathrm{~g} / \mathrm{dl}$ in men. It appears reasonable to elevate the haemoglobin level in anaemic cancer patients into this optimal range. This may be achieved with red blood cell transfusions (RBCT) or erythropoiesis stimulating agents (ESAs). However, RBCT have had negligible or even negative effect on patient outcome, possibly because RBCT induce immunosuppression or result in haemoglobin levels too high for optimal tumour oxygenation. Several randomized trials have demonstrated that patients irradiated for head-and-neck cancer had worse outcomes with ESAs than the control group. However, in the majority of these trials, over-treatment with ESAs resulted in haemoglobin levels above the optimal range. Tumour oxygenation is impaired by inappropriately high haemoglobin levels due to increased blood viscosity and decreased tumour cell perfusion. This concept is supported by the findings of prospective studies in cervix cancer and esophageal cancer patients. In these studies the ESA administration was withheld at a haemoglobin level of $14 \mathrm{~g} / \mathrm{dl}$ resulting in a positive effect of ESAs on treatment outcome. In summary, the effect of RBCT and particularly of ESAs during radiotherapy remains unclear. Further randomized trials are required. Until such trials are available, one should follow the ASCO and ESMO guidelines that are very conservative regarding the administration of ESAs during radiotherapy and chemoradiation.

Keywords: Anaemia correction, chemoradiation, erythropoiesis stimulating agents, radiotherapy, red blood cell transfusions

\section{Introduction}

Controversy exists regarding the benefit of anaemia correction during radiotherapy or chemoradiation of solid tumours.

Correspondence: Dirk Rades, MD, Department of Radiation Oncology, University Hospital Schleswig-Holstein, Campus Lubeck, Ratzeburger Allee 160, 23538 Lubeck, Germany.

E-mail: rades.dirk@gmx.net
The correction of anaemia can be achieved with red blood cell transfusions (RBCT) or erythropoiesis stimulating agents (ESAs). ESAs were demonstrated to be effective in improving fatigue and quality of life in patients with chemotherapy-induced anaemia over 15 years ago [1]. However, a recent metaanalysis including individual data from 13,933 cancer patients who participated in 53 randomized trials suggested that the use of ESAs was negatively associated with survival [2]. Similar results were found in another meta-analysis of 1,397 patients from five randomized trials of radiotherapy for head-and-neck cancer [3].

The limitation of both meta-analyses was the fact that the haemoglobin levels were pushed quite high by administration of ESAs in a considerable proportion of patients. This is particularly important in regards to the effectiveness of radiotherapy depending on optimal tumour oxygenation. According to radiobiological studies, tumour hypoxia impairs the production of radiation-induced cytotoxic free radicals leading to less DNA damage and tumour cell kill. Tumour oxygenation can be impaired by both anaemia and inappropriately high haemoglobin levels. High haemoglobin levels lead to increased blood viscosity and decreased perfusion of the tumour cells [4]. In addition, high haemoglobin levels predispose to pathologic clot formation. Haemoglobin levels must be $12-14 \mathrm{~g} / \mathrm{dl}$ in women and $13-15 \mathrm{~g} / \mathrm{dl}$ in men to achieve optimal tumour oxygenation and the best results from radiotherapy [5]. These data have been confirmed in a retrospective study of 108 oesophageal cancer patients, where haemoglobin levels during radiotherapy of $12-14 \mathrm{~g} / \mathrm{dl}$ resulted in better 2-year loco-regional control than levels $<12 \mathrm{~g} / \mathrm{dl}$ or $>14 \mathrm{~g} / \mathrm{dl}(58 \%$ vs. $19 \%$ and $44 \%, p<0.001)$ [6]. In another retrospective study of 181 patients with non-small cell lung cancer, haemoglobin levels during radiotherapy of $<12 \mathrm{~g} / \mathrm{dl}$ were associated with significantly lower 2-year loco-regional control (29 vs. 41\%, $p=0.004$ ) and 2-year overall survival rates (41 vs. 58\%, $p=0.013$ ) when compared to haemoglobin levels during radiotherapy of $\geq 12 \mathrm{~g} / \mathrm{dl}[7]$.

Considering the radiobiological data regarding optimal tumour oxygenation, it appears reasonable to take a closer look at the studies investigating the administration of RBCT or ESAs in cancer patients treated with radiotherapy or chemoradiation. 


\section{Red blood cell transfusions (RBCT)}

In 1995, Kelleher et al. suggested that worsening of tumour oxygenation due to anaemia could partially be reversed by administration of ESAs and RBCT in rats [8]. However, this effect was observed only for small tumours. In tumours $\geq 1.4 \mathrm{ml}$, anaemia correction did not significantly improve tumour oxygenation. In a retrospective analysis of 204 patients irradiated for cervix cancer, the response to RBCT was disappointing [9]. Non-responders to RBCT had poor outcomes in terms of disease-free survival, pelvic control, and metastases-free survival. In another retrospective series of 605 patients irradiated for cervix cancer, RBCT were positively associated with treatment outcomes on univariate but not on multivariate analysis [10]. RBCT were negatively associated with survival in a series of 130 patients irradiated for cervix cancer (RR: 2.2; $p<0.001$ ) [11]. It is possible that the haemoglobin levels in patients receiving RBCT were increased beyond the range considered optimal for tumour oxygenation. Unfortunately, the proportions of haemoglobin levels during radiotherapy of $>14 \mathrm{~g} / \mathrm{dl}$ in women and $>15 \mathrm{~g} / \mathrm{dl}$ in men were not stated. A recently published randomized study from Denmark investigated RBCT in 414 patients with squamous cell carcinoma of the head-and-neck (SCCHN) [12]. Pre-radiotherapy haemoglobin levels of $<13 \mathrm{~g} / \mathrm{dl}$ in women and $<14.5 \mathrm{~g} / \mathrm{dl}$ in men were defined as "low". RBCT was given to achieve haemoglobin levels in the "high" level range. Patients of the "high" level group had significantly better loco-regional control (LRC), disease-specific survival (DSS), and overall survival (OS) than patients with "low" pre-radiotherapy haemoglobin levels. In the "low" level group, RBCT had no significant benefit on LRC (HR 0.99; $p=0.9$ ), DSS (HR 1.07; $p=0.8$ ), and OS (HR: 1.10; $p=0.6$ ). Again, it is possible that the haemoglobin levels in the patients receiving RBCT were higher than the optimal range for tumour oxygenation. The unsatisfying results after RBCT may also be explained by the fact that RBCT can cause immunosuppression [13]. Because RBCT showed no benefit or a negative impact on outcome after radiotherapy, radiation oncologists have been looking for alternative options to correct anaemia and improve tumour oxygenation during radiotherapy. This led to studies investigating the potential benefit of ESAs.

\section{Erythropoietin stimulating agents (ESAs)}

Currently, radiation oncologists are hesitant to use ESAs with radiotherapy, as several randomized trials have demonstrated no benefit or even a negative effect with respect to treatment outcomes. In 2003, the ENHANCE study was published that investigated the impact of epoetin beta in 351 patients irradiated for SCCHN [14]. Loco-regional control (RR: 1.69, $p=0.007$ ) and survival (RR: $1.39, p=0.02$ ) were significantly better in the placebo group than in the epoetin beta group. However, this study was criticized because the study groups were not balanced for relevant prognostic factors and because about one-third of patients were not treated per protocol. Furthermore, $82 \%$ of the patients in the epoetin beta groups had haemoglobin levels greater than the optimal range for tumour oxygenation in comparison to only $15 \%$ of patients in the placebo group. Taking into account the importance of optimal tumour oxygenation for the effectiveness of radiotherapy, it is no surprise that the placebo group did better than the (over-treated) epoetin beta group.

In 2007, the Radiation Therapy Oncology Group 99-03 trial evaluated the role of weekly erythropoietin in 141 evaluable patients receiving concurrent chemoradiation and/or accelerated radiotherapy for SCCHN [15]. The 3-year locoregional failure rates were $44 \%$ in the erythropoietin group and $36 \%$ in the control group ( $p=0.56)$. The 3 -year overall survival rates were $56 \%$ and $57 \%$, respectively.

The final results of a randomized trial from Denmark (DAHANCA 10) were presented in 2009 [16]. The impact of darbepoetin alfa on treatment outcomes was investigated in 522 patients irradiated for SCCHN. The 5-year loco-regional control rates were 59\% in the darbepoetin group and $68 \%$ in the control group, respectively (RR: $1.47, p=0.04$ ). The 5 -year disease-free survival rates were $37 \%$ and $47 \%$, respectively (RR: $1.32, p=0.02$ ), and the 5 -year overall survival rates were $37 \%$ and $47 \%$, respectively (RR: $1.20, p=0.16$ ). The target haemoglobin range in the DAHANCA 10 was $14-15.5 \mathrm{~g} / \mathrm{dl}$, which was like in the ENHANCE study and beyond the optimal range for tumour oxygenation. Therefore, the prognosis of the patients in the control group was likely to be better than in the darbepoetin group due to over-treatment with darbepoetin.

In 2009, a randomized trial from the United Kingdom including 301 patients irradiated for SCCHN was published [17]. In contrast to the previous studies, an on-and-off strategy was used to avoid over-treatment with epoetin alfa. If the haemoglobin level became $>15 \mathrm{~g} / \mathrm{dl}$, epoetin alfa was withheld until the haemoglobin level was $<14.5 \mathrm{~g} / \mathrm{dl}$ and restarted at $50 \%$ of the previous dose. Taking into account the optimal range for tumour oxygenation, the haemoglobin levels still were too high. According to that trial, the 5-year local diseasefree survival rates were $41 \%$ in the epoetin alfa group and $44 \%$ in the control group, respectively $(p=0.79)$, and the 5 -year overall survival rates were $49 \%$ and $50 \%$, respectively $(p=0.82)$.

In contrast to the four randomized trials of SCCHN, a recently published randomized trial of 257 patients receiving chemoradiation for cervix cancer showed a strong trend towards improved recurrence-free survival with the administration of epoetin alfa (HR: $0.66, p=0.06$ ) [18]. Overall survival was not significantly different (HR: $0.88, p=0.63$ ). A significant benefit of epoetin alfa regarding recurrence-free survival was observed for patients with stage IB-IIA disease (HR: 0.39, $p=0.014$ ) and patients having a complete resection (HR: 0.55, $p=0.039$ ). These results favouring epoetin alfa may be explained by the fact that in this trial, the epoetin alfa dose was reduced to $33 \%$ when the haemoglobin level reached $13 \mathrm{~g} / \mathrm{dl}$, and discontinued at $14 \mathrm{~g} / \mathrm{dl}$. A benefit on treatment outcome with epoetin alfa was also observed in a prospective observational study of 96 patients receiving chemoradiation for oesophageal cancer [19]. In that study, epoetin alfa was started at haemoglobin levels $<13 \mathrm{~g} / \mathrm{dl}$ and stopped at $14 \mathrm{~g} / \mathrm{dl}$. Due to this on-and-off strategy, $64 \%$ patients of the epoetin alfa group had the majority of weekly haemoglobin levels within the optimal range of $12-14 \mathrm{~g} / \mathrm{dl}$ compared to only $17 \%$ in the control group.

The results of all the previously mentioned studies and meta-analyses regarding the administration of ESAs might have been influenced by tumour expression of erythropoietin and its receptor EPO-R. A retrospective analysis of patients 
from the ENHANCE study suggested that tumour cell expression of EPO-R had a negative impact on treatment outcomes of patients receiving epoetin beta during radiotherapy [20]. Another retrospective study suggested that patients with low tumour expression of EPO-R and erythropoietin who received epoetin alfa during radiotherapy had better outcomes [21]. Furthermore, the results of the previously mentioned studies and meta-analyses might have been influenced by the patients' smoking habit, as smoking during radiotherapy has been shown to impair tumour oxygenation. This has been shown in particular for non-small cell lung cancer and headand-neck cancer [7, 22-24]. In a retrospective study of 181 patients with non-small cell lung cancer, loco-regional control at 2 years was better in patients who did not smoke than in patients who did smoke during radiotherapy ( $58 \%$ vs. $41 \%$, $p<0.001)$ [7]. In another retrospective study of 151 patients with non-small cell lung cancer, patients who had stopped smoking at the time of initial consultation (prior to surgery and postoperative radiotherapy) had a significantly better loco-regional control at 5 years $(77 \%$ vs. $52 \%, p=0.002)$ than patients who continued to smoke [22]. In the retrospective study of Kawakita et al. of 222 patients with cancer of the oral cavity, non-smokers and light smokers ( $<30$ pack years) had significantly better 5 -year overall survival rates than moderate (31-59 pack years) and heavy smokers ( $\geq 60$ pack years) [24]. The adjusted hazard ratios for moderate and heavy smokers versus light smokers were $2.44(1.07-5.57, p=0.034)$ and $2.66(0.97-7.33, p=0.058)$. The adjusted hazard ratio for non-smokers versus light smokers was 2.27 (0.84-6.15, $p=0.11$ ).

ESAs have also been discussed in lymphoma patients, e.g. in patients receiving radiotherapy after autologous stem cell transplantation (ASCT). However, the data are very scarce. In 1998, Toren et al. reported grade 4 haematological toxicities requiring interruption of radiotherapy for more than one week in 11 of 93 patients $(12 \%)$ who had received involved-field irradiation after ASCT [25]. Patients with malignant lymphoma were at a significantly higher risk of developing radiation-induced cytopenia than those patients with solid tumours ( $28 \%$ versus $5 \%, p<0.05)$. Of the patients with a Non-Hodgkin's lymphoma, 8 of 14 (57\%) patients who received the radiotherapy as planned and 6 of $7(86 \%)$ patients who had a radiotherapy break of more than one week relapsed $(p<0.05)$. Thus, there may be a potential role for ESAs

Tab. 1: American Society of Clinical Oncology/American Society of Hematology clinical practice guideline for the use of ESAs. Dosing of ESAs in adults (modified according to [26])

\begin{tabular}{|c|c|c|c|c|}
\hline & \multicolumn{2}{|l|}{ Epoetin alfa } & \multicolumn{2}{|l|}{ Darbepoetin alfa } \\
\hline Initial dose & $\begin{array}{l}150 \mathrm{IU} / \mathrm{kg} \text { s.c. } 3 \mathrm{x} / \mathrm{week} \text { (not } \\
\text { initiated at } \mathrm{Hb} \text { levels } \geq 10 \mathrm{~g} / \mathrm{dl} \text { ) }\end{array}$ & $\begin{array}{l}40,000 \mathrm{IU} \text { s.c. } 1 \mathrm{x} / \text { week (not } \\
\text { initiated at } \mathrm{Hb} \text { levels } \geq 10 \mathrm{~g} / \mathrm{dl} \text { ) }\end{array}$ & $\begin{array}{l}2.25 \mu \mathrm{g} / \mathrm{kg} \text { s.c. } 1 \mathrm{x} / \mathrm{week} \text { (not } \\
\text { initiated at Hb levels } \geq 10 \mathrm{~g} / \mathrm{dl} \text { ) }\end{array}$ & $\begin{array}{l}500 \mu \mathrm{g} \text { s.c. every } 3 \text { wks. (not } \\
\text { initiated at } \mathrm{Hb} \text { levels } \geq 10 \mathrm{~g} / \mathrm{dl} \text { ) }\end{array}$ \\
\hline Dose increase & $\begin{array}{l}\text { Increase dose to } 300 \mathrm{IU} / \mathrm{kg} \\
3 \mathrm{x} / \text { week if no reduction in } \\
\text { transfusion requirements or } \mathrm{Hb} \\
\text { increase after } 4 \text { weeks }\end{array}$ & $\begin{array}{l}\text { Increase dose to } 60,000 \mathrm{IU} 1 \mathrm{x} / \\
\text { week if no increase in } \mathrm{Hb} \text { by } \\
\geq 1 \mathrm{~g} / \mathrm{dl} \text { after } 4 \text { weeks (absence } \\
\text { of RBCT) }\end{array}$ & $\begin{array}{l}\text { Increase dose up to } 4.5 \mu \mathrm{gg} / \mathrm{kg} \\
\text { if there is }<1 \mathrm{~g} / \mathrm{dl} \text { increase in } \\
\mathrm{Hb} \text { after } 6 \text { weeks of therapy }\end{array}$ & Not recommended \\
\hline Dose reduction & \multicolumn{2}{|c|}{$\begin{array}{l}\text { Decrease dose by } 25 \% \text { when } \mathrm{Hb} \text { reaches a level needed to avoid } \\
\text { transfusion or } \mathrm{Hb} \text { increases }>1 \mathrm{~g} / \mathrm{dl} \text { in } 2 \text { weeks }\end{array}$} & \multicolumn{2}{|c|}{$\begin{array}{l}\text { Decrease dose by } 40 \% \text { of previous dose when } \mathrm{Hb} \text { reaches a level } \\
\text { needed to avoid transfusion or } \mathrm{Hb} \text { increases to }>1 \mathrm{~g} / \mathrm{dl} \text { in } 2 \text { weeks }\end{array}$} \\
\hline Dose withholding & \multicolumn{2}{|c|}{$\begin{array}{l}\text { If } \mathrm{Hb} \text { exceeds a level needed to avoid transfusion; restart dose } \\
\text { at } 25 \% \text { below previous dose when } \mathrm{Hb} \text { approaches a level where } \\
\text { transfusion may be required }\end{array}$} & \multicolumn{2}{|c|}{$\begin{array}{l}\text { If } \mathrm{Hb} \text { exceeds a level needed to avoid transfusion; restart dose } \\
\text { at } 40 \% \text { below previous dose when } \mathrm{Hb} \text { approaches a level where } \\
\text { transfusion may be required }\end{array}$} \\
\hline Discontinue & \multicolumn{2}{|c|}{$\begin{array}{l}\text { Following completion of CT course or if no response after } 8 \\
\text { weeks of therapy (measured by } \mathrm{Hb} \text { levels or continuing need for } \\
\text { transfusions) }\end{array}$} & \multicolumn{2}{|c|}{$\begin{array}{l}\text { Following completion of CT course or if no response after } 8 \\
\text { weeks of therapy (measured by } \mathrm{Hb} \text { levels or continuing need for } \\
\text { transfusions) }\end{array}$} \\
\hline
\end{tabular}

Tab. 2: ESMO clinical practice guidelines for the use of ESAs. The EMEA labels the use of ESAs

as follows [27]: - chemotherapy and haemoglobin level $\leq 10 \mathrm{~g} / \mathrm{dll}$ : ESAs might be considered to increase haemoglobin

to $<2 \mathrm{~g} / \mathrm{dl}$ or to avoid further decline of the haemoglobin level. - no chemotherapy: no indication for ESAs; there might be an increased risk of death when the target haemoglobin level is $12-14 \mathrm{~g} / \mathrm{dl}$. - curative treatment: ESAs should be used with caution.

Treatment recommendations according to label (EMEA) (modified according to [23])

\begin{tabular}{|c|c|c|c|}
\hline & Epoetin alfa & Epoetin beta & Darbepoetin \\
\hline Initial treatment & $\begin{array}{l}150 \mathrm{IU} / \mathrm{kg} \text { s.c. } 3 \mathrm{x} / \text { week } 450 \\
\text { IU/kg s.c. } 1 \text { x/week }\end{array}$ & 30,000 IU s.c. $1 x /$ week & $\begin{array}{l}2.25 \mu \mathrm{g} / \mathrm{kg} \mathrm{s.c.} 1 \mathrm{x} / \text { week } \\
500 \mu \mathrm{g}(6.75 \mu \mathrm{g} / \mathrm{kg}) \text { s.c. every } 3 \text { weeks }\end{array}$ \\
\hline Dose increase & $300 \mathrm{IU} / \mathrm{kg}$ s.c. $3 \mathrm{x} /$ week & 60,000 IU s.c. $1 x /$ week & Not recommended \\
\hline Dose reduction by $25-50 \%$ & $\begin{array}{l}\text { If result achieved } \\
\text { If } \mathrm{Hb}>12 \mathrm{~g} / \mathrm{dl} \\
\text { If } \mathrm{Hb} \text { rise }>2 \mathrm{~g} / \mathrm{d} / 4 \text { weeks }\end{array}$ & $\begin{array}{l}\text { If result achieved } \\
\text { If } \mathrm{Hb}>12 \mathrm{~g} / \mathrm{dl} \\
\text { If } \mathrm{Hb} \text { rise }>2 \mathrm{~g} / \mathrm{d} / 4 \text { weeks }\end{array}$ & $\begin{array}{l}\text { If result achieved } \\
\text { If } \mathrm{Hb}>12 \mathrm{~g} / \mathrm{dl} \\
\text { If } \mathrm{Hb} \text { rise }>2 \mathrm{~g} / \mathrm{d} / 4 \text { weeks }\end{array}$ \\
\hline Dose withholding & If $\mathrm{Hb}>13 \mathrm{~g} / \mathrm{dl}$ until $12 \mathrm{~g} / \mathrm{dl}$ & If $\mathrm{Hb}>13 \mathrm{~g} / \mathrm{dl}$ until $12 \mathrm{~g} / \mathrm{dl}$ & If $\mathrm{Hb}>13 \mathrm{~g} / \mathrm{dl}$ until $12 \mathrm{~g} / \mathrm{dl}$ \\
\hline
\end{tabular}


and G-CSF in order to avoid cytopenia-induced radiotherapy breaks. However, the scarce data available do not allow serious conclusions regarding the use of ESAs in these patients.

\section{Conclusions}

It appears important to maintain the haemoglobin levels within the optimal range for tumour oxygenation (12-14 g/dl in women and $13-15 \mathrm{~g} / \mathrm{dl}$ in men) to achieve the maximum effect of radiotherapy. The role of RBCT and in particular of ESAs for irradiated cancer patients treated remains unclear. Randomized trials using cautious strategies of ESA administration during radiotherapy and considering tumour expression of EPO-R and erythropoietin are required. Such trials should consider the ASCO guidelines (ESA adult dosing recommendations given in Table 1) and ESMO guidelines (treatment recommendations according to the European Medicines Agency EMEA given in Table 2) [26, 27]. Both guidelines are extremely reserved regarding the use of ESAs in patients receiving radiotherapy. So are several meta-analyses [2, 28, 29]. The association between haemoglobin levels, tumour oxygenation, and effectiveness of radiotherapy remains complex and requires further investigation.

\section{Take home message}

It appears important to maintain the haemoglobin levels during radiotherapy within the optimal range for tumour oxygenation $(12-14 \mathrm{~g} / \mathrm{dl}$ in women and $13-15 \mathrm{~g} / \mathrm{dl}$ in men) to achieve the best treatment outcome. The role of RBCT and ESAs remains unclear and needs to be clarified by randomized trials employing strategies that aim at maintenance of an optimal haemoglobin concentration. The ASCO and ESMO guidelines aid the clinician when considering correction of anaemia in the individual patient.

\section{Conflict of interest}

The authors declare that there is no conflict of interest.

\section{References}

[1] Henry DH, Abels RI. Recombinant human erythropoietin in the treatment of cancer and chemotherapy-induced anaemia: results of double-blind and open-label follow up studies. Semin Oncol, 21: 21-8, 1994.

[2] Bohlius J, Schmidlin K, Brillant C, et al. Recombinant human erythropoiesis-stimulating agents and mortality in patients with cancer: a meta-analysis of randomised trials. Lancet, 373: 1537-42, 2009.

[3] Lambin P, Ramaekers BL, vam Mastrigt GA, et al. Erythropoietin as an adjuvant treatment with (chemo) radiation therapy for head and neck cancer. Cochrane Database Syst Rev, CD006158, 2009.

[4] Vaupel P, Thews O, Mayer A, Hockel S, Hockel M. Oxygenation status of gynecologic tumors: what is the optimal hemoglobin level? Strahlenther Onkol, 178: 727-31, 2002.

[5] Vaupel P, Mayer A, Hockel M. Impact of hemoglobin levels on tumor oxygenation: the higher, the better? Strahlenther Onkol, 182: 63-71, 2006.

[6] Rades D, Lang S, Schild SE, Alberti W. Prognostic value of haemoglobin levels during concurrent radio-chemotherapy in the treatment of oesophageal cancer. Clin Oncol, 18: 139-44, 2006.

[7] Rades D, Setter C, Schild SE, Dunst J. Effect of smoking during radiotherapy, respiratory insufficiency, and hemoglobin levels on outcome in patients irradiated for non-small-cell lung cancer. Int J Radiat Oncol Biol Phys, 71: 1134-42, 2008.

[8] Kelleher DK, Matthiensen U, Thews O, Vaupel P. Tumor oxygenation in anemic rats: effects of erythropoietin treatment versus red blood cell transfusion. Acta Oncol, 34: 379-84, 1995.
[9] Kapp KS, Poschauko J, Geyer E, et al. Evaluation of the effect of routine packed red blood cell transfusion in anemic cervix cancer patients treated with radical radiotherapy. Int J Radiat Oncol Biol Phys, 54: 58-66, 2002.

[10] Grogan M, Thomas GM, Melamed I, et al. The importance of hemoglobin levels during radiotherapy for carcinoma of the cervix. Cancer, 86: 1528-36, 1999.

[11] Santin AD, Bellone S, Parrish RS, et al. Influence of allogenic blood transfusion on clinical outcome during radiotherapy for cancer of the uterine cervix. Gynecol Obstet Invest, 56: 28-34, 2002.

[12] Hoff CM, Hansen HS, Overgaard M, et al. The importance of haemoglobin level and effect of transfusion in HNSCC patients treated with radiotherapy-results from the randomized DAHANCA 5 study. Radiother Oncol, 98: 28-33, 2011.

[13] Santin AD, Bellone S, Palmieri M, et al. Effect of blood transfusion during radiotherapy on the immune function of patients with cancer of the uterine cervix: role of interleukin-10. Int J Radiat Oncol Biol Phys, 54: 1345-55, 2002.

[14] Henke M, Laszig R, Rube C, et al. Erythropoietin to treat head and neck cancer patients with anaemia undergoing radiotherapy: randomised, double-blind, placebo-controlled trial. Lancet, 362: 125560, 2003.

[15] Machtay M, Pajak TF, Suntharalingam M, et al. Radiotherapy with or without erythropoietin for anemic patients with head and neck cancer: a randomized trial of the Radiation Therapy Oncology Group (RTOG 99-03). Int J Radiat Oncol Biol Phys, 69: 1008-17, 2007.

[16] Overgaard J, Hoff CM, Sand-Hansen HS, et al. Randomized study of darbepoetin alfa as modifier of radiotherapy in patients with primary squamous cell carcinoma of the head and neck (HNSCC). Final outcome of the DAHANCA 10 trial. J Clin Oncol, 27:abstr 6007, 2009.

[17] Hoskin PJ, Robinson M, Slevin N, Morgan D, Harrington K, Gaffney C. Effect of epoetin alfa on survival and cancer treatment-related anemia and fatigue in patients receiving radical radiotherapy with curative intent for head and neck cancer. J Clin Oncol, 27: 5751-6, 2009.

[18] Blohmer JU, Paepke S, Sehouli J, et al. Randomized phase III trial of sequential adjuvant chemoradiotherapy with or without erythropoietin alfa in patients with high-risk cervical cancer: results of the AGO- and NOGGO-intergroup study. J Clin Oncol, 29: 3791-7, 2011.

[19] Rades D, Tribius S, Yekebas EF, et al. Epoetin alfa improves survival after chemoradiation for stage III esophageal cancer: final results of a prospective observational study. Int J Radiat Oncol Biol Phys, 65: 459-65, 2006.

[20] Henke M, Mattern D, Pepe M, et al. Do erythropoietin receptors on cancer cells explain unexpected clinical findings? J Clin Oncol, 24: 4708-13, 2006.

[21] Rades D, Gohlke H, Schild SE, Kilic E. The impact of tumor expression of erythropoietin receptors (Epo-R) and erythropoietin (Epo) on clinical outcome of esophageal cancer patients treated with chemoradiation. Int J Radiat Oncol Biol Phys, 71: 152-9, 2008.

[22] Nguyen SK, Masson-Cote L, Fortin A, Dagnault A. Influence of smoking status on treatment outcomes after post-operative radiation therapy for non-small-cell lung cancer. Radiother Oncol, 96: 88-93, 2010.

[23] Granata R, Miceli R, Orlandi E, et al. Tumor stage, human papillomavirus and smoking status affect the survival of patients with oropharyngeal cancer: an Italian validation study. Ann Oncol, in press.

[24] Kawakita D, Hosono S, Ito H, et al. Impact of smoking status on clinical outcome in oral cavity cancer patients. Oral Oncol, 48: 186-91, 2012.

[25] Toren A, Nagler R, Nagler A. Involved field radiation post autologous stem cell transplantation in lymphoma patients is associated with major haematological toxicities. Med Oncol, 15: 113-8, 1998.

[26] Rizzo JD, Brouwers M, Hurley P, et al. American Society of Clinical Oncology/American Society of Hematology clinical practice guideline update on the use of epoetin and darbepoetin in adult patients with cancer. J Clin Oncol, 28: 4996-5010, 2010.

[27] Schrijvers D, De Samblanx H, Rolla F, et al. Erythropoesis-stimulating agents in the treatment of anaemia in cancer patients: ESMO clinical practice guidelines for use. Ann Oncol, 21:(Suppl. 5): v244-7, 2010.

[28] Bohlius J, Schmidlin K, Brillant C, et al. Erythropoietin or Darbepoetin for patients with cancer-meta-analysis based on individual patient data. Cochrane Database Syst Rev, CD007303, 2009.

[29] Bohlius J, Tonia T, Schwarzer G. Twist and shout: one decade of meta-analyses of erythropoiesis-stimulating agents in cancer patients Acta Haematol, 125: 55-67, 2011. 